DOI https://doi.org/10.36059/978-966-397-235-0-3

\author{
Вдовічена Л. I., \\ кандидат юридичних наук, \\ доцент кафедри публічного права \\ юридичного факультету \\ Чернівецького національного університету \\ імені Юрія Федьковича, \\ м. Чернівці
}

\title{
ПРАВО ВИМОГИ У ФІНАНСОВОМУ ПРАВІ
}

Анотація. У проведеному досліджені визначається, що право вимоги - це структурний елемент суб'єктивного фінансового права, який виражається у юридично захищеній можливості дій певної особи та забезпечується відповідними обов'язками або зв'язаністю дій кореспондуючих осіб, зміст яких (дій) полягає у спроможності такою особою їх самостійно визначати та вимагати вчинення дії від інших осіб, а також захищати своє право у встановленому законом порядку. Зміст будь-якого суб'єктивного права можна звести до системи певних можливостей його носія: поводити себе певним чином (право на свої власні дії); вимагати певної поведінки від інших суб'єктів (право на чужі дії - право вимоги); звертатися до держави та ії органів за захистом свого юридичного права (право на захист). Для права вимоги у фінансовому праві характерні такі особливості: право вимоги стає беззмістовним, якщо воно не пов'язане з можливістю користування якимись соціальними благами; право вимоги $\epsilon$ лище різновидом власних дій уповноваженої особи; при негативному праві вимоги використання права на власні дії в юридичному аспекті не потребує сприяння зобов'язаних осіб, їх число невизначено, не персоніфіковане; право вимоги активних дій припускає конкретний склад юридично зобов'язаних суб'єктів, $i$ без їхніх дій уповноважений суб'єкт не може здійснити своє право - в даному випадку правовідносини є необхідними. 


\section{Вступ}

Право вимоги, як і суб'єктивне право загалом, окреслене певними правовими нормами, тобто представляє собою міру належної, необхідної поведінки. Вимагати виконання обов'язків поза встановленою мірою $є$ порушенням закону. Закріплення у нормах права, у тому числі в Конституції, прав вимоги за своєю сутністю $є$ проявом дозволу як особливого правового способу регламентації суспільних відносин. Водночас слід мати на увазі, що правовий дозвіл на здійснення суб'єктом певної поведінки шляхом закріплення за ним можливостей (прав) буде реальним лише за наявності юридичних обов'язків інших суб'єктів діяти відповідно до вимог уповноваженого суб'єкта.

У цілому зміст суб'єктивного права складають права i обов'язки. Проте, як однопорядковий, однорівневий 3 об'єктивним правом структурний елемент системи права, право в суб'єктивному значенні визначається як абстрактна, загальна система прав, свобод та обов'язків. Сюди ж можна віднести і такі суб'єктивні прояви, як законні інтереси та навіть рефлекси права. Тоді як на іншому рівні свого буття - правовідносин, право в суб'єктивному змісті визначається як персоніфікована правомочність, прерогатива (або їх сукупність) конкретної особи, що володіє ними. Тут суб'єктивне право розуміється як явище відмінне від обов'язків уповноваженої особи, які асоціюються 3 контрагентними суб'єктами правовідношень. Крім того, на цьому рівні суб'єктивне право вимоги також видозмінюється через вплив законних інтересів та відповідних рефлексів права. Отже, залежно від рівня прояву, в суб'єктивному праві спостерігається рухливість і мінливість змісту. На думку авторів навчального посібника «Фінансове право (За законодавством України)», суб'єктивні права - «це належна уповноваженій особі (фінансовому чи кредитному органу) для задоволення ії (тобто держави, від імені якої він виступає) інтересів міра дозволеної (можливої) поведінки, забезпечена юридичними обов'язками другої сторони відносин» [1, с. 43]. Із цим твердженням можна погодитися лише частково. Особливості фінансових правовідносин та методу фінансово-правового регулювання обгрунтовують існування принципу нерівності сторін у фінансових правовідносинах, одним із суб'єктів завжди виступає сама держава або муніципальне утворення в особі уповноваженого органу, що володіють владними 
повноваженнями. Але це не заперечує можливість існування суб'єктивних прав в інших суб'єктів фінансового права (юридичних чи фізичних осіб), що зумовлено змістом їхньої фінансової правосуб'єктності, у першу чергу у фінансовоохоронних відносинах з приводу захисту своїх інтересів у адміністративному і судовому порядку, і ці права виступають як правові гарантії діяльності фізичних та юридичних осіб. Крім того, на сьогодні простежується тенденція до лібералізації фінансового законодавства, зменшення питомої ваги категорично сформульованих фінансово-правових норм i запровадження диспозитивних начал у поведінці суб'єктів фінансового права. Саме це сприяє розвитку сучасної концепції фінансового права, основою якого $\epsilon$ визнання, регламентація та гарантування задоволення публічних потреб та інтересів. Така концепція, враховуючи їі модифікованість і особливості, зумовлена сучасним рівнем і характером світової цивілізації, спирається на багатий минулий досвід людства і, насамперед, - у сфері правових форм організації суспільного життя людей, правових засобів регуляції їх поведінки, місця, ролі і значення у цивілізованому світі. Тому, безперечно, із функціонуванням суб'єктів фінансового права тісно пов'язують питання прояву публічного інтересу [2, с. 5-10]. Адже поняття публічного інтересу, як взагалі будь-яке правове явище, існує не окремо, а у зв'язку з іншими правовими поняттями. Взаємозв'язок суб'єктів фінансового права з публічним інтересом виявляється в тому, що саме в результаті здійснення ними відповідних, встановлених законодавством дій, можлива реалізація публічного інтересу в суспільстві. Тобто всі дії учасників фінансових правовідносин певною мірою спрямовані на виконання публічного інтересу в цілому. У правовій науці виділяють поняття публічного та приватного інтересу. Сама ж категорія інтересу не $є$ виключно правовою і досліджується також філософією, соціологією, педагогікою, психологією, іншими.

Специфічна особливість суб'єктів фінансового права полягає у майже стовідсотковій реалізації у конкретних правовідносинах закладеної у нормах права фінансової правосуб'єктності. Цей факт, а також складність відмежування прав від обов'язків стосовно органів, які здійснюють публічну фінансову діяльність, спричинили певні труднощі для науки фінансового права. Складно-видовий характер норм фінансового права призводить 
Права людини в Україні та у зарубіжних країнах: традиції та новації

до того, що формування фінансової правосуб'єктності відбувається не універсально, а у звуженому обсязі, тобто не на підставі норм, які торкаються усіх видів фінансових правовідносин, а саме в межах окремих фінансово-правових розділів та інститутів. Це веде до неоднорідного найменування суб'єктів фінансового права у різних сферах фінансової діяльності: в податковому праві - це суб'єкт оподаткування, платник податку, податковий орган, податковий агент; у бюджетному праві - бюджетний орган, бюджетна організація, розпорядник бюджетних кредитів; у банківському праві - банк, позичальник, власник банківського рахунку; в страховому праві страховик, страхувальник, перестрахувальник; у валютному праві - резидент, нерезидент, орган валютного контролю тощо.

Без динаміки суб'єктивного фінансового права законодавство України відірвалося б від реального соціального руху і перетворилося в «мертву» схему логічно зв'язаних норм [3, с. 185]. У загальному вигляді зміст суб'єктивного фінансового права можна звести до того, що воно надає уповноваженому суб'єкту такі можливості:

1) поводити себе відповідним чином (право на свої дії);

2) вимагати відповідної поведінки від інших суб'єктів (право вимоги);

3) звертатися до держави за захистом свого юридичного права.

Тому зміст будь-якого суб’єктивного права можна звести до системи певних можливостей його носія. Це можливості: поводити себе певним чином (право на свої власні дії); вимагати певної поведінки від інших суб'єктів (право на чужі дії - право вимоги); звертатися до держави та її органів за, захистом свого юридичного права (право на захист) [4]. Із цього чітко вбачається, що наявності самих лише уповноважуючих приписів, тобто таких, що фіксують дозвіл можливості конкретної поведінки даного суб'єкта фінансового права (але одночасно не зобов'язують інших суб'єктів до здійснення певної поведінки, а також не забороняють поведінки, що перешкоджає реалізації можливої поведінки уповноваженого суб'єкта) досить лише для реального здійснення права на власні дії уповноваженого суб'єкта. У цьому випадку, тобто спираючись виключно на даний йому дозвіл здійснювати можливу поведінку, суб'єкт лише у невеликій кількості ситуацій може досягнути певного 
соціального блага, що й $є$ кінцевою метою і сенсом реалізації можливостей, що утворюють зміст суб'єктивних фінансових прав. Йтися може тільки про поведінку, яка не потребує якогось спеціального (організаційного, матеріального тощо) забезпечення з боку інших суб'єктів, яке знаходить свій вираз у праві на чужі дії (право вимоги). Задоволення інтересів суб'єктів фінансового права часто визначається діями інших осіб, так як такі дії безумовно є імперативними обов'язками зобов'язаних осіб, що характерно для публічної галузі права. Таким чином, суб'єктивне фінансове право визнається правом як на свої, так i на чужі дії. Момент вимоги це один з найважливіших моментів у визначенні суб'єктивного права, адже воно тотожне можливості, що перебуває під охороною держави.

Для того, щоб повно та ефективно здійснити право вимоги, одних лише уповноважуючих норм недостатньо. Необхідне також існування кореспондуючих ним зобов'язуючих норм, які тією чи іншою мірою зафіксували необхідну поведінку, тобто конкретні обов'язки відповідних суб'єктів здійснювати певні дії (або утримуватись від них) на вимогу уповноважених суб'єктів. I тому основний зміст суб'єктивного права вимоги зумовлюється інтересом, для задоволення якого існує потреба в поведінці зобов'язаних осіб.

\section{1. Принципи реалізації права вимоги у фінансовому праві}

У випадках, коли здійснення суб'єктивних прав спрямоване на реалізацію можливої поведінки, спрямованої на вимогу певної поведінки від інших суб'єктів (право вимоги), то така реалізація може відбуватися виключно в межах правових відносин. А це означає, що від волі та поведінки уповноваженої сторони повною мірою залежить лише початок процесу реалізації, тобто здійснення дій, які спрямовані на виникнення правовідносин, у межах яких вона сподівається реалізувати свою можливу поведінку. Саме тому вирішальне значення для реалізації права вимоги уповноваженого суб'єкта мають значення принципи суб'єктивного права, адже право вимоги визначається як його основний елемент поряд із правом на власні дії та правом на захист.

Принципи реалізації права вимоги у фінансовому праві пронизують усю юридичну форму суспільних відносин, виражаючи в кінцевому рахунку основні підвалини існуючого ладу фінансових правовідносин. Принцип забезпеченості права вимоги у 
Права людини в Україні та у зарубіжних країнах: традиції та новації

фінансовому праві, сутність якого полягає в тому, що держава зобов'язана матеріально, організаційно, юридично (через об'єктивне право і спеціально-юридичний механізм тощо) забезпечувати реалізацію суб'єктивних прав. А це, у свою чергу, надає суб'єктам можливість вимагати від держави відповідного забезпечення реалізації повноважень, що випливають 3 того чи іншого суб'єктивного фінансового права. Із даного принципу випливає такий принцип фінансового права як принцип формальної рівності суб'єктів фінансових правовідносин [5, с. 11].

Принцип демократизму права вимоги у фінансовому праві полягає у тому, що публічні фінанси $\epsilon$ мірою досягнутого у суспільстві прогресу, згідно з якою визначається і забезпечується фінансова свобода суб'єкта. Окрім того, права вимоги у фінансовому праві і само $є$ правовим інструментом розвитку демократії у суспільстві на основі принципів гуманізму і свободи.

Принци активності права вимоги у фінансовому праві зумовлений тим, що саме воно забезпечує громадянам та іншим його носіям можливість активної участі в усіх сферах фінансового життя і тим самим активізує ці сфери. Суб'єктивне фінансове право $\epsilon$ основою системи юридичних та інших засобів забезпечення участі громадян і організацій у найважливіших сферах соціальних відносин (сфера соціального забезпечення).

Принцип фінансового заохочення суспільно корисної поведінки означає, що права вимоги як вид і міра можливої, дозволеної поведінки суб'єкта у суспільстві $€$ найкращим стимулятором правомірної поведінки, зменшення зловживань фінансовими правами, яка приносить користь і суспільству в цілому, і окремому суб'єктові (наприклад, надання податкових пільг).

Принци безпосередності права вимоги у фінансовому праві зумовлений тим, що останнє виступає найкращим показником пануючих у суспільстві поглядів на демократію, гуманізм, права людини.

Принцип реальності права вимоги у фінансовому праві забезпечує становище, за яким суб'єктивне право стає інструментом викриття перекручень, забезпечення досягнень суспільства у правовій системі; виступає дійовим показником досягнень або ж відставання суспільства у цій сфері; дає можливість визначити реальне становище особи як вищої цінності у державі і суспільстві. 
Права людини в Україні та у зарубіжних країнах: традиції та новації

Принцип гуманізму права вимоги у фінансовому праві притаманний суб'єктивному фінансовому праву тому, що останнє виступає регулятором поведінки суб'єктів права шляхом фіксації певних еталонів поведінки, які відповідають інтересам суспільства, а не інтересам держави.

Принцип свободи вбачається у визначенні через право вимоги у фінансовому праві системи взаємних юридичних прав i обов'язків суб'єктів фінансового права i в такий спосіб забезпеченні відповідної міри свободи.

Принцип законності щодо права вимоги у фінансовому праві має визначатися як такий, що слугує інструментом поєднання фінансового порядку і організованості, дотримання фінансових законів і підзаконних актів із забезпеченням певної активності і оперативної самостійності суб'єктів фінансового права.

Принцип справедливості дає можливість уявити, якою міроюу суб'єктивному фінансовому праві дістають вияв загальнолюдські цінності, компроміс між приватними і публічними інтересами і потребами суб’єктів фінансового права [6].

Принцип регулятивності у суб'єктивному праві - $€$ засобом упорядкування фінансових правовідносин і дозволяє суб'єктам права вимоги у фінансовому праві планувати свою поведінку і прогнозувати поведінку інших суб'єктів. Адже саме суб'єктивне фінансове право визначає систему конкретних повноважень суб'єктів у найважливіших сферах фінансових відносин, $\epsilon$ юридичним інструментом набуття суб'єктами фінансового права тих чи інших соціальних та матеріальних благ [7].

Розуміння права вимоги у фінансовому праві супроводжується непослідовністю, суперечністю і однобічністю людського логосу, що не зважає на вимоги наукової логіки. Фактичність розуміння права вимоги не знаходить згоди 3 аксіоматичними положеннями про нерозривність прав та обов'язків. Такі права і обов'язки, що становлять в єдності зміст правової норми, з якої виводиться поняття об'єктивного права, 3 необхідністю транслюються в його зміст. Доктринальне уявлення про діалектичну підпорядкованість суб'єктивного права праву об'єктивному повинно приводити до припущення про відповідність в їх змісті на рівні прав та обов'язків.

Регулятивний вплив фінансового права досягає своєї кульмінації з погляду забезпечення публічних потреб та реалізації суспільних інтересів. Від структури суб'єктивного фінансового 
права, характеру складових його елементів (і в тому числі права вимоги) залежить можливість його реалізації поза конкретними правовідносинами. Як ми уже відзначали, особливістю суб'єктивного фінансового права вимоги $\epsilon$ те, що благо, яким прагне користуватися уповноважений суб'єкт, частіше за все $є$ загальним суспільним благом (публічні фінанси), тому і право на користування таким благом чітко регламентоване державою. Саме тому важливим в частині реалізації права вимоги $\epsilon$ визначення системи критеріїв правового регулювання, котрі забезпечують можливість його здійснення. Тому звертаємо увагу на такі критерії принципу адекватності правового регулювання правовідносин, як критерій недостатності, критерій придатності, критерій можливості [8].

Критерій недостатності чинного правового регулювання. Правове значення категорії недостатності полягає в тому, що заходи, які існують на визначений момент, не можуть повністю забезпечити правове регулювання відповідного кола суспільних відносин. Питання достатності правового регулювання пов'язане 3 встановленням межі, за якою дії держави стають невідповідними, оскільки ці дії є недостатніми для досягнення певної цілі. Проте це не стосується кола ситуацій, коли для досягнення певної цілі не створено належних та достатніх умов, тобто коли йдеться про недостатність певного виду правового регулювання, зокрема неможливість виконання конституційного обов'язку зі сплати податку без прийняття деталізуючи нормативно-правових актів. Так, у статті 67 Конституції України зазначено, що кожен зобов'язаний сплачувати податки та збори в розмірах та строках встановлених в законі [9]. I оскільки податкове зобов'язання $є$ ядром податкового права, то через реалізацію цих норм розкривається соціальна цінність і кінцева мета всієї системи податково-правового регулювання. Досліджуючи можливість застосування даної категорії до податкового права, необхідно зазначити, що загально відомий принцип однобічного запровадження податків та примусового їх стягнення не суперечить трактуванню фіскальних правовідносин як системи специфічних зобов'язань, що складаються між державою, з одного боку, та індивідуальними і колективними суб'єктами оподаткування, 3 іншого. Це беззаперечний приклад правового регулювання права вимоги у податковому праві. Однак, як показує практика, лише 
конституційної норми недостатньо для повного врегулювання системи оподаткування. Справа в тому, що будь-які норми і правила, встановлювані в конституційному порядку, не можуть врахувати всіх розходжень і особливостей систем оподаткування, що існують, тобто різні податкові ставки, правила і норми визначення оподатковуваного доходу, різні пільги, відрахування і т.д. Усі ці питання можуть бути погоджені лише в рамках деталізованого, прийнятого на виконання норм Конституції України законодавства - Податковому кодексі України.

Критерій придатності вже наявного правового регулювання реалізації права вимоги. Непридатне правове регулювання фінансових відносин можна вважати неадекватним, оскільки воно передбачає таке втручання у права, яке $\epsilon$ нездатним для досягнення потрібної легітимної цілі. Даний критерій слугує продовженням дії критерію недостатності, оскільки існуюче правове регулювання може бути недостатнім внаслідок застосування таких методів, які $є$ непридатними, або ж в силу економічного розвитку стали непридатними. Ця, на перший погляд, досить тривіальна, констатація при докладнішому розгляді породжує чимало запитань, зокрема: як визначити непридатність; коли їі потрібно визначати? Відповіді на ці запитання залежать від їхнього хронологічного порядку, а він, у свою чергу, від застосування принципу соціального натуралізму [10]. Практика нас переконує, що саме від того, як і правотворці, i правокористувачі розуміють право, залежить і те, як вони його використовують. Правильне (найбільш адекватне, відповідне його природі) розуміння права зумовлює успішне правокористування, а якась абсолютизація окремих аспектів права породжує великі проблеми у правозастосуванні. Досвід Європи орієнтує нас на те, що до розуміння права на сучасному етапі і правотворення, і правозастосування в Україні ефективно можна було б застосувати принцип «соціального натуралізму». Очевидно, що принцип соціального натуралізму вимагає відповісти на це запитання таким чином: у творенні права беруть участь як природа, так і люди. Природа створює зміст права, а люди, тобто об'єднання людей у формі держави, надають праву більш-менш адекватну або зовсім неадекватну природному змісту форму. Так, із позицій принципу соціального натуралізму податкове право має дві сторони - природний зміст і соціальну форму - нормативне вираження. Форма і зміст є атрибутами одне 
одного, у природному стані неможливі одне без одного. Найдосконалішою $є$ така юридична структура податку, коли його природний зміст адекватно втілюється у законодавстві. Аналізуючи українське податкове законодавство, можна побачити повне ігнорування державою дійсної правової природи податку при встановленні елементів юридичної структури податку. Це головна причина того, що український законодавець, визначаючи юридичну конструкцію податку як родового явища та видові юридичні конструкції окремих податків, кожного разу позначає їх іншою групою елементів, що суттєво різняться між собою та неадекватно відображають правову природу цього суспільного явища. Поза досконалими юридичними конструкціями податку позитивне податкове право не може набути довершених, зрілих форм, стати ефективним регулятором податкових відносин у суспільстві. Тому вирішуючи питання, коли потрібно кваліфікувати придатність певної дії, слід враховувати, що людина, на яку положено такі обов'язки, повинна 3 цілковитою впевненістю «зазирнути» у майбутнє. Отже, з юридичної точки зору, потрібно вимагати, щоб особи 3 правом рішення на момент його прийняття уже чітко могли оцінити свій конкретний захід на предмет того, як точно він діятиме і які чинники впливатимуть на його дію.

Критерій можливості застосування наявного правового регулювання суб'єктами права вимоги для яких воно призначене. Наступний критерій, який необхідно ввести у методологію прийняття та введення виваженого правового регулювання, - це критерій можливості, тобто здатність адресата виконати те, що вимагається законом чи міжнародним договором. Так, критерій можливості в частині реалізації права вимоги можна продемонструвати при застосуванні відповідальності за бюджетні правопорушення. Адже єдине, що було визначено БК України в редакції 2001 року, це те, що під бюджетним правопорушенням розумілося недотримання учасником бюджетного процесу встановленого цим Кодексом та іншими нормативно-правовими актами порядку складання, розгляду, затвердження змін, виконання бюджету чи звіту про виконання бюджету (ст. 116) [11]. I тому деталізація бюджетних правопорушень виступала предметом скоріш науковопрактичних коментарів кодексу, аніж безпосередньо законодавчих актів. Адже питання застосування юридичної 
Права людини в Україні та у зарубіжних країнах: традиції та новації

відповідальності за бюджетні правопорушення в частині накладення заходів фінансової відповідальності були спущені на підзаконний рівень (прикладом може бути Указ Президента України № 1251/2001 від 25.12.2001 р. «Про зміцнення фінансової дисципліни та запобігання правопорушенням у бюджетній сфері») [12]. Відповідальні посадові особи органів державної влади, які контролювали діяльність у бюджетній сфері, мали опиратися лише на норми Бюджетного кодексу (статті 109-125) [13]; Кодексу України про адміністративні правопорушення (ст. 164-12) [14] та Кримінального кодексу України (статті 210-211) [15]. Така ситуація викликала постійну критику з боку практиків. Неодноразово констатувався той факт, що питання відповідальності за порушення бюджетного законодавства врегульовані не в належному обсязі; не здійснено належним чином розподіл компетенції між органами державної влади та місцевого самоврядування у сфері контролю за дотриманням бюджетного законодавства.

\section{2. Право вимоги у податково-правовому зобов'язанні}

Досліджуючи можливість застосування даної категорії до податкового права, необхідно зазначити, що загально відомий принцип однобічного запровадження податків та примусового їх стягнення не суперечить трактуванню фіскальних правовідносин як системи специфічних зобов'язань, що складаються між державою, з одного боку, та індивідуальними і колективними суб'єктами оподаткування, з іншого, адже з точки зору цивільно-правової доктрини, про яку уже згадувалось, за ознакою підстав виникнення розрізняє договірні та позадоговірні зобов'язання. Податкове зобов'язання можна визначити як юридичну конструкцію 3 конкретизованою законом метою. Мета податкового зобов'язання - безумовна i безвідплатна передача певних грошових коштів від податкового боржника податковому кредитору для формування публічної власності, основне призначення якої покриття публічних потреб. Однак, як відзначає I.I. Бабін, поняття «податкового зобов'язання» доцільно використовувати для позначення правовідношення, в якому податковий орган володіє правом вимоги, а платник податків зобов'язаний здійснити дії по передачі певної суми грошових коштів до бюджету. Саме в такому значенні воно використовується в Податковому кодексі 
Права людини в Україні та у зарубіжних країнах: традиції та новації

України при визначенні видових юридичних конструкцій податку [16, с. 196].

Однак у такому ракурсі реалізується право вимоги лише держави в особі уповноваженого державного органу. Тобто тут податкове зобов'язання можна розглядати як правовідношення між державою і платником, в силу якого платник зобов'язується сплатити до бюджету відповідну суму коштів (у вигляді податку або збору) на підставах, у порядку і в строки, визначені законом. Однак у податковому зобов'язанні існує ще й інший ракурс - коли уповноважений суб'єктом із правом вимоги виступає платник податків - правовідношення між державою і платником, де в силу обставин держава (в особі уповноваженого державного органу) виступає зобов'язаним суб'єктом по відношенню до нього. Йдеться в першу чергу про відносини повернення сум переплаченого податку (в т.ч. відшкодування ПДВ), а також обов'язки держави, які виникають у зв'язку 3 виконання платником своїх зобов'язань по сплаті податків (надання розстрочки i відстрочки сплати податкового зобов'язання, списання податкового боргу тощо [6, с.187]).

Крім того, аналізуючи норми податкового законодавства, можна провести паралель та виділити податкові права вимоги уповноважених державних контрольних органів та кореспондуючі ним обов'язки платника податків. Відповідне структурування та уточнення прав податкових органів (митних органів), їхнє чітке визначення сприятиме забезпеченню та захисту інтересів підконтрольних суб'єктів. Тому нам імпонує розподіл прав податкових органів, запропонований М.П. Кучерявенком, який пропонує розділити останні на такі групи: контрольні, організаційні, облікові, інформаційні [17, с. 106], на основі яких ми і проведемо паралель групування змісту прав вимоги у податковому зобов'язанні.

організаційні права вимоги передбачають можливості застосування права вимоги податкових органів у сфері координації процесу сплати податків: право вимоги уповноважених державних органів сплатити податок (запрошувати платників податків або їх представників для перевірки правильності нарахування та своєчасності сплати податків та зборів, дотримання вимог іншого законодавства, здійснення контролю за дотриманням якого покладено на органи державної податкової служби. Так, державні податкові 
Права людини в Україні та у зарубіжних країнах: традиції та новації

органи мають право вимоги на методичну та практичну допомогу від вищестоящих органів; 3 іншої сторони - право вимагати вилучення документів і предметів у платника податків в якості доказів, викликати в податкові органи для встановлення певного факту та ін.

Облікові права вимоги податкових органів полягають у можливості вимагати отримання інформації від платника податків з метою поставлення його на облік, а також право на отримання інформації та відомостей від платника податків 3 метою визначення суми його податкового зобов'язання, методичне керівництво бухгалтерським обліком і звітність підприємств, прийняття заходів по їх удосконаленню, затвердження планів розрахунків платників податків та ін. Так, цій групі прав вимоги кореспондується обов'язок платника податків визначений у статті 16 ПКУ, зокрема платник податків зобов'язаний: стати на облік у контролюючих органах у порядку, встановленому законодавством України [18].

Інформаційні права вимоги передбачають можливості для податкових органів використовувати засоби масової інформації як для інформування платників податків з метою удосконалення процесу сплати податків, так і для отримання інформації для підвищення ефективності власної діяльності. Так, стаття 20.1.3. ПКУ передбачає, що органи державної податкової служби мають право: одержувати безоплатно від платників податків, а також від установ Національного банку України, банків та інших фінансових установ довідки, у порядку встановленому Законом України «Про банки і банківську діяльність» (2121-14 ) та цим Кодексом, довідки та/або копії документів про наявність банківських рахунків, а на підставі рішення суду - інформацію про обсяг та обіг коштів на рахунках, у тому числі про ненадходження у встановлені терміни валютної виручки від суб’єктів підприємницької діяльності [18].

Контрольні права вимоги податкових органів полягають у можливості здійснювати перевірку та безпосередньо контролювати процес сплати податків: проведення податкових перевірок, отримання від платників податків необхідних документів, виявлення, розкриття і попередження податкових правопорушень та ін. Так, стаття 20.1.5. ПКУ передбачає, що органи державної податкової служби мають право: вимагати від платників податків, що перевіряються в ході перевірок, 
Права людини в Україні та у зарубіжних країнах: традиції та новації

проведення інвентаризації основних фондів, товарноматеріальних цінностей, коштів, у тому числі зняття залишків товарно-матеріальних цінностей, готівки.

Тепер спробуємо визначити права вимоги у податковому зобов'язанні з іншого ракурсу, тобто зі сторони платника податків. 3 усього наведеного у статті 17 ПКУ переліку прав платників податків можна умовно провести їхнє групування, в основі якого буде лежати функціональна спрямованість вказаних прав: права організаційного характеру; права щодо сплати податків; права з обліку та звітності. Ми ж таку саму паралель проведемо в ракурсі права вимоги.

Права вимоги зі сплати податків передбачають можливості для платника податків вимагати від податкових органів дотримуватися Конституції України та діяти виключно у відповідності з ПКУ та іншими законами України, іншими нормативними актами; забезпечувати сумлінне виконання покладених на контролюючі органи функцій; забезпечувати ефективну роботу та виконання завдань контролюючих органів відповідно до їхніх повноважень; не допускати порушень прав та охоронюваних законом інтересів громадян, підприємств, установ, організацій; коректно та уважно ставитися до платників податків, їхніх представників та інших учасників відносин, що виникають під час реалізації норм цього Кодексу та інших законів, не принижувати їхніх честі та гідності; право вимагати скористатися податковими пільгами, отримати розстрочку платежу, відстрочку сплати податку, отримання податкового кредиту [19, с. 156]. Наприклад, у ст. 14.1.181. Податкового кодексу України передбачено право платника податку на додану вартість на отримання податкового кредиту - «податковий кредит - сума, на яку платник податку на додану вартість має право зменшити податкове зобов'язання звітного (податкового) періоду, визначена згідно з розділом V цього Кодексу» [18].

Права вимоги організаційного характеру передбачають можливості платника податків представляти свої інтереси безпосередньо (або через представника) в податкових органах, а також бути присутнім при проведенні податкових перевірок, безоплатно отримувати в органах державної податкової служби та в митних органах, у тому числі і через мережу Інтернет, інформацію про податки та збори і нормативно-правові акти, що їх регулюють, порядок обліку та сплати податків та зборів, права 
та обов'язки платників податків, повноваження контролюючих органів та їх посадових осіб щодо здійснення податкового контролю [20, с. 125]. Платник податків має право вимагати від контролюючих органів проведення перевірки відомостей та фактів, що можуть свідчити на користь платника податків. Крім того, шкода, завдана неправомірними діями посадових осіб контролюючих органів, підлягає відшкодуванню за рахунок коштів державного бюджету, передбачених таким контролюючим органам.

Права вимоги з обліку та звітності полягають в можливості платника податку вимагати одержувати в податкових органах необхідну інформацію, вибирати засіб проведення податкового обліку, оскаржувати рішення податкових органів, надавати податковим органам пояснення, обгрунтовані відмови. Так, в ст 46.4 Податкового кодексу України зазначено, що якщо платник податків вважає, що форма податкової декларації, визначена центральним контролюючим органом, збільшує або зменшує його податкові зобов'язання, всупереч нормам цього Кодексу з такого податку чи збору, він має право зазначити цей факт у спеціально відведеному місці в податковій декларації. У разі необхідності платник податків може подати разом з такою податковою декларацією доповнення до такої декларації, які складені за довільною формою, що вважатиметься невід'ємною частиною податкової декларації. Таке доповнення подається з поясненням мотивів його подання [18], а також обирати самостійно, якщо інше не встановлено ПКУ, метод ведення обліку доходів і витрат.

Однак настільки широкий спектр прав вимоги як для платників податків, так і для податкових контрольних органів створює умови для супутнього негативного явища в правозастосування - зловживання правом вимоги. Багато науковців в теорії податкового права питання зловживання податковим правом розглядали виключно з точки зору дій платників податків. Часто виділяють два типи зловживання правами з боку платника податків: по-перше, зловживання суб'єктивними правами, що випливають з положень приватного права; по-друге, зловживання власне суб'єктивними податковими правами. Проблема зловживання правом, навіть у епоху сучасності, залишається однією $з$ найактуальніших і не тільки в Україні. У континентальній Європі, вперше, єдину 
Права людини в Україні та у зарубіжних країнах: традиції та новації

теорію зловживання суб'єктивними правами виробила французька судова практика в XIX ст., яка грунтувалась на нормах права про відповідальність за шкоду, хоча в Цивільному кодексі Франції 1804 p. не містилося прямих заборон зловживання правами. Ідея «abus de droit» (фр. зловживання правом) саме у Франції отримала своє остаточне закріплення. У 1915 р. Касаційним судом Франції було прийнято правило, згідно з яким встановлювалася відповідальність власника, який використовує своє суб'єктивне право на шкоду іншому власнику і без користі для себе. Згодом, у законодавстві континентальної Європи закріпилася розуміння зловживання правом через мету завдати шкоди іншій особі [21, с. 42].

Звичайно, що наявність загальних і спеціальних заборон у даний час характерно для законодавства різних правових систем i це не повинно розглядатися як недолік. Так, у деяких країнах (наприклад, в Японії) наявність прямої конституційної заборони на зловживання правом, який, безумовно, носить загальний характер, межує із забороною на зловживання цивільними правами, закріпленим в ЦК, який в даному випадку необхідно розглядати в якості спеціального (галузевого) принципу. Крім того, в наукові літературі часто акцентується на зв'язку зловживання правом із суб'єктивними правами - зловживання правом $\epsilon$ свідомо неправильним здійсненням суб'єктивного права: 1) дії щодо здійснення права не повинні прямо порушувати правової норми, а можуть бути самі по собі допустимими, можливими; 2) такі дії в даному конкретному випадку здійснюються для досягнення цілей, які не відповідають цілям і функцій, у зв'язку з якою правовою нормою передбачено суб'єктивні права; 3) ці дії вчиняються з наміром завдати шкоди іншим особам або погіршити їх майнове або суспільне становище; 4) дії, про які йдеться, здійснюються носіями суб'єктивного права, що не має при цьому виправданого інтересу.

Досить часто, підходячи до вирішення проблеми попередження зловживанням правом через нормативне закріплення відповідної правової заборони, робиться застереження, що не допускається зловживання платниками податків, податковими агентами, а також особами, які забезпечують надходження податків до бюджету і позабюджетні фонди, наданими законодавством правами шляхом вчинення правомірних дій, спрямованих на умисне ухилення або 
Права людини в Україні та у зарубіжних країнах: традиції та новації

неправомірне звільнення від сплати податків або перешкоджання проведенню податкового контролю. При цьому, як бачимо, в основу ознак зловживання правом ставляться правомірні дії зобов'язаних осіб. Визначення зловживання правом «шляхом вчинення правомірних дій» веде до змішування різних правових явищ - дозволеної поведінки і неприпустимих правових наслідків.

Також досить часто зловживання правом вимоги у сфері податкових правовідносин властиво тільки діям платників податків, вказуючи у зв'язку з цим на те, що не допускається зловживання платником податків правами, наданими йому законодавством, що виразилося в умисних діях платника податків, спрямованих виключно на зменшення або виключення (усунення) ним своїх податкових зобов'язань.

Найбільш прийнятим у правовій науці стало розуміння зловживання правом, як неприпустимої поведінки, спрямованої на умисне невиконання вимог закону або заподіяння шкоди іншій особі, зокрема: «Зловживанням правом вимоги визнається умисне використання передбачених законодавством пільг, переваг, форм діяльності, а так само вчинення інших дій, що характеризується удаваністю або удаваною метою або юридичною підставою, а також умисна бездіяльність, спрямована на невиконання обов'язків, встановлених законодавством про податки і збори» [22, с. 92]. Крім того, можливо в податковому праві взагалі немає необхідності встановлювати норми про зловживання правом, оскільки в податкових правовідносинах платнику податків завжди протистоїть тільки держава, і ця обставина визначає коло наданих платнику податку прав - йому дано тільки той мінімум прав, які він може використовувати виключно в своїх інтересах [23, с. 79]. Тому часто відзначається, що податковими правами вимоги неможливо зловживати, оскільки вони надані платнику податку саме для того, щоб він міг захиститися від держави, зокрема від контролюючих органів. I для запобігання можливих проявів зловживанням правом вимоги досить позбавити платника податків цього права і закріпити відповідний обов'язок.

Такий підхід звужує поняття зловживання правом вимоги в податкових правовідносинах у ракурсі виключно дій платників податків, адже варто виділити і зловживання правом 3 боку податкових органів. Також можна зазначити, що наявність відповідного права вимоги саме по собі не свідчить про можливість зловживання таким правом. Це може проявлятися в 
Права людини в Україні та у зарубіжних країнах: традиції та новації

разі навмисної реалізації відповідного права вимоги за рамками дозволених i допустимих законом меж їx здійснення. Повертаючись до питання про прояв зловживання правом 3 точки зору суб'єктного складу, слід ще раз підкреслити, що теза про можливість зловживання правом вимоги лише зі сторони платника податків, нераціональна, оскільки законодавче закріплення прав за конкретним учасником податкових правовідносин спочатку створює передумови для можливості відповідного суб'єкта зловживати такими правами.

Отже, правам вимоги уповноваженого суб'єкта кореспондуються обов'язки зобов'язаного суб'єкта. Однак характеристика податкового зобов'язання показує, що в даному правовідношенні існує і зворотній зв'язок. У результаті виконання обов'язків зі сплати податків у платників податків виникають теж права вимоги до органів державної влади (податкових органів), котрі зумовлені самою природою податку та податкових правовідносин.

\section{3. Право вимоги у бюджетно-правовому зобов'язанні}

Однією з особливостей права вимоги у фінансовому праві $\epsilon$ те, що у переважній більшості випадків правом вимоги наділені уповноважені державні органи, які представляють державу в бюджетних правовідносинах, та уповноважені органи місцевого самоврядування, які представляють адміністративнотериторіальні утворення. Однак аналіз бюджетного законодавства не дає однозначної відповіді на правову природу категорії «бюджетне зобов'язання». Так, згідно зі статтею 2 Бюджетного кодексу України, бюджетне зобов'язання - будь-яке здійснене відповідно до бюджетного асигнування розміщення замовлення, укладення договору, придбання товару, послуги чи здійснення інших аналогічних операцій протягом бюджетного періоду, згідно з якими необхідно здійснити платежі протягом цього ж періоду або у майбутньому [13]. Таким чином, бюджетне зобов'язання за Бюджетним кодексом $\epsilon$ правовідношенням між розпорядником бюджетних коштів та іншими особами, що поставляють товар, надають послуги або виконують роботи, за рахунок бюджетних коштів. Згідно із чинним законодавством усі бюджетні зобов'язання підлягають реєстрації і можуть здійснюватися лише в межах бюджетних асигнувань.

Для характеристики права вимоги у бюджетному зобов'язанні, в першу чергу, необхідно виділити, що відносини з 
приводу використання публічно-територіальними утвореннями бюджетних коштів відносяться до зобов'язальних відносин. Крім того, видатки бюджету пов'язанні з переміщенням майна у формі бюджетних (грошових) засобів з бюджету до отримувача цих коштів. За правовою природою це є відносини активного виду, що підтверджує механізм реалізації обов'язків суб'єктів бюджетних відносин. Згідно 3 аналізом механізму відносин здійснення бюджетних видатків випливає, що отримувачу бюджетних коштів протиставляється чітко визначений зобов'язаний суб'єкт - суспільно-територіальне утворення, що здійснює регулювання видатків. Такі відносини називаються відносними. Звідси випливає ще одна ознака бюджетних зобов'язальних відносин - їхній відносний характер. Але категорія бюджетного зобов'язання нерозривно пов'язана із суб'єктивним бюджетним правом. Так, суб'єктивне бюджетне право зумовлює безпосередній зв'язок уповноваженого та зобов'язаного суб'єктів, а його реалізація залежить не лише від власних дій, а й від дій (або утримання від дій) зобов'язаного суб'єкта. Особливість бюджетного суб'єктивного права зумовлюється суб'єктним складом цих правовідносин, що передбачає обов'язкову наявність такого суб'єкта як уповноважений державою орган. Для такого уповноваженого органу всі права, зумовлені його завданнями та функціями, не $\epsilon$ правами в класичному розумінні, тобто такими, які він може реалізовувати чи не реалізовувати на власний розсуд, а в широкому плані $\epsilon$ виконанням обов'язків перед державою. Тому суб'єктивне бюджетне право уповноваженого суб'єкта визначають як «право-обов'язок».

Суб'єктивне бюджетне право уповноваженого суб'єкта, на думку В.Д. Чернадчук, залежить від виду бюджетних правовідносин [24]. У пасивних бюджетних правовідносинах переважає право на власні дії, які уповноважений суб'єкт зобов'язаний здійснити, оскільки держава надає таким суб'єктам необхідні для виконання завдань і функцій можливості. Реалізація останніх $\epsilon$ їх обов'язком перед державою. Обов'язок інших суб'єктів - не перешкоджати уповноваженому суб'єкту в реалізації цих прав-обов'язків. Але право на позитивні дії не тотожне праву вимоги цих суб'єктів в активних бюджетних правовідносинах, оскільки надає уповноваженому суб'єкту право вибору. Особливістю права на позитивні дії, як зазначає М.П. Кучерявенко, $\epsilon$ специфічно замкнена індивідуальність, в умовах якої реалізація 
цього права не пов'язана з діями інших осіб, їх впливом i сприянням цьому праву [25, с. 439]. В активних бюджетних правовідносинах право на позитивні дії завжди поєднано з правом вимагати від інших суб'єктів утримуватися від здійснення дій, що перешкоджають реалізації суб'єктивного бюджетного права. Так, право вимоги в бюджетних правовідносинах мають уповноважені державні органи та органи місцевого самоврядування. Узяття бюджетних зобов'язань $€$ невід'ємним механізмом, якщо бути точніше - невід'ємною складовою третьої стадії виконання бюджету (не має значення, державний чи місцевий бюджет) за видатками. Обов'язкова наявність бюджетного зобов'язання в процесі реалізації розпорядниками бюджетних коштів своїх повноважень демонструється навіть у тому, що нова редакції Бюджетного кодексу України від 2010 року не внесла жодних змін у визначення цього поняття. Необхідно відзначити два моменти, що мають істотне значення для розкриття поняття права вимоги у бюджетному зобов'язанні. По-перше, бюджетне зобов'язання, якщо виходити з його розуміння в межах ч. 7 ст. 2 Бюджетного кодексу України, не може виникнути між державними органами, державними органами і органами місцевого самоврядування, а також між безпосередньо органами місцевого самоврядування, тобто тими, хто виступає розпорядниками бюджетних коштів (незалежно від рівня - головні чи нижчестоящі). Хоча практика засвідчує, що в деяких випадках виконання робіт чи надання послуг може здійснюватися і у ланцюгу «розпорядник коштів» «розпорядник коштів». У такому разі доцільно виходити із загального визначення учасників бюджетного процесу, під якими БК України розуміє органи, установи та посадових осіб, наділених бюджетними повноваженнями (правами та обов'язками 3 управління бюджетними коштами) (ч. 3 ст. 19) [13].

По-друге, виходячи з розуміння бюджетного зобов'язання, його не може бути там, де немає «розміщення замовлення, укладення договору, придбання товару, послуги чи здійснення інших аналогічних операцій». Водночас, згідно з тією ж статтею 2 Бюджетного кодексу, під платежем розуміється погашення зобов'язання, яке виникло в поточному або попередніх бюджетних періодах [13]. Таким чином, будь-якому платежу повинне передувати виникнення зобов'язання, або, скажемо по-іншому, платіж поза межами виконання зобов'язання (або платіж, що виникає не у процесі виконання зобов'язання) в бюджетних відносинах $є$ неможливим. Виходячи з викладеного, 
Права людини в Україні та у зарубіжних країнах: традиції та новації

було б логічним передбачити, що якщо бюджетні кошти надаються 3 державного бюджету місцевому бюджету як міжбюджетний трансферт (субвенція, дотація) шляхом здійснення платежу, то такий платіж здійснюється на виконання зобов'язань державного бюджету перед бюджетом місцевим.

Більш того, досить логічною була б вимога органу місцевого самоврядування про надання йому дотацій, субвенцій 3 державного бюджету на підставах та в обсягах, розрахованих згідно з положеннями глав 15, 16 Бюджетного кодексу України. Таке право органу місцевого самоврядування абсолютно відповідало б принципу відповідальності учасників бюджетного процесу, котрий був задекларований статтею 7 БК України, а в новій редакції Бюджетного кодексу України 2010 року був виключений [13]. Тим більше, що законодавець, приймаючи нову редакцію Бюджетного кодексу України, намагався хоча б певною мірою урегулювати процеси децентралізації місцевого самоврядування, у даному випадку - у фінансово-правовій (бюджетній) сфері. Це можна прослідкувати, зокрема, на деталізації міжбюджетних трансфертів, закладених у новій редакції кодексу. Крім того, бюджетні зобов'язання відносить до фінансово-правових зобов'язань видаткового типу. Фінансові зобов'язання видаткового типу - це асигнування з бюджетних установ, засоби на сплату товарів, робіт та послуг за муніципальними та державними контрактами, трансферти для здійснення виплат громадянам, інвестиції у статутні капітали існуючих чи створюваних державних організацій тощо. Їхня типологія $\epsilon$ менш чіткою і досить динамічною, але це не перешкоджає об'єднати всі зобов'язання видаткового типу в одну загальна категорію - видаткові зобов'язання. Крім того, норми Бюджетного кодексу України не дають позитивної відповіді на питання щодо можливості розпоряднику бюджетних коштів варіювати свою поведінку при виконанні бюджетних зобов'язань чи сподіватися на якесь відшкодування. Так, визначаючи особливості здійснення окремих видатків бюджету, кодексом закріплено, що розпорядники бюджетних коштів забезпечують у повному обсязі проведення розрахунків за електричну та теплову енергію, водопостачання, водовідведення, природний газ та послуги зв'язку, які споживаються бюджетними установами, та укладають договори за кожним видом енергоносіїв у межах встановлених відповідним головним розпорядником бюджетних коштів обгрунтованих лімітів 
Права людини в Україні та у зарубіжних країнах: традиції та новації

споживання. При цьому кодекс не визначає, що робити розпоряднику за умови відсутності належного обсягу фінансування, з чим нині, за умов виходу з фінансової кризи та зростаючих щорічних виплат по державному боргу, стикається практично увесь бюджетний сектор.

Отже, в бюджетних правовідносинах право вимоги реалізується у формі активних дій - вимога до зобов'язаного суб'єкта виконати активні обов'язки - тут право вимоги передбачає здійснення зобов'язаним суб'єктом комплексу активних дій, пов'язаних із виконанням суб'єктивного бюджетного обов'язку. Правом вимоги у бюджетному зобов'язанні наділено, згідно із законодавством, учасників бюджетного процесу, під якими БК України розуміє органи, установи та посадових осіб, наділених бюджетними повноваженнями (правами та обов'язками 3 управління бюджетними коштами). Крім того, право вимоги не може бути там, де немає «розміщення замовлення, укладення договору, придбання товару, послуги чи здійснення інших аналогічних операцій». Однак це $\epsilon$ спірним моментом у визначенні права вимоги у бюджетному зобов'язанні, оскільки в даному випадку законодавець не враховує випадки виконання таких зобов'язань між самими ж розпорядниками бюджетних коштів, а також не враховує права вимоги місцевих бюджетів на дотації та субвенції (міжбюджетні трансферти), котрі встановлюються Законом України «Про державний бюджет України» на поточний рік.

Ще одним важливим моментом у реалізації права вимоги $\epsilon$ це забезпечення його об'єктивізації. Основне завдання позитивного права полягає в тому, щоб перейняти зміст природного права, розвити його у вигляді ряду норм зовнішньої поведінки, пристосовуючи їх до умов суспільного життя i до потреб належного часу, надати цим нормам змістовну форму та смислове закріплення і проникнути у свідомість людей у ролі авторитетного зобов'язуючого веління. Позитивне право $\epsilon$ раціональна форма підтримання природного права вимоги.

Збалансування публічного та приватного інтересів виступає ключовим принципом в правовій державі, свого роду парадигмою фінансового права. Без постійного врахування могутнього впливу цього фактору на приватні і публічні фінанси, на опосередковуючі їх податки не можна не тільки побудувати фінансову систему в суспільстві в якості публічних фінансів, але і створити умови для найбільш оптимальних пропорцій і темпів 
Права людини в Україні та у зарубіжних країнах: традиції та новації

суспільного розвитку, найбільш повного задоволення зростаючих публічних та приватних потреб.

Продемонструвати залежність права вимоги від принципів можна на прикладі податкового права. Дійсні принципи податкового права можна виявити саме з позицій природнопозитивного підходу до податкового права. Яскравим підтвердженням цього висновку є результати, отримані в процесі дослідження принципів податкового права Г.А. Гаджиєвим і С.Г. Пепеляєвим. Керуючись принципом соціального натуралізму, вони прийшли до висновку, що найбільш природною $\epsilon$ класифікація основних принципів оподатковування і зборів «у залежності від спрямованості дії» вирішуваних з їх допомогою задач, тобто функціональна класифікація. За цим критерієм вони виділили три групи принципів: а) принципи, що забезпечують реалізацію i дотримання основ конституційного ладу; б) принципи, що забезпечують реалізацію і дотримання основних прав і свобод платників податків; в) принципи, що забезпечують реалізацію і дотримання основ федералізму. До першої групи принципів вони віднесли: принцип публічної мети стягнення податків і зборів; принцип пріоритету фінансової мети податків і зборів; принцип обмеження спеціалізації податків і зборів; принцип встановлення, зміни чи скасування податків і зборів законами; принцип встановлення податків і зборів у належній процедурі; принцип обмеження форм податкової законотворчості. До другої групи принципів вони віднесли: принцип юридичної рівності платників податків і зборів; принцип загальності оподатковування; принцип рівного податкового тягаря; принцип співрозмірності оподатковування конституційно значущим цілям обмеження прав і свобод. До третьої групи принципів вони віднесли: принцип єдності податкової політики; принцип єдності системи податків; принцип координації i поділу податкових повноважень [26, с. 194-197].

Ще один із напрямів об'єктивізації права вимоги є норми Конституції держави, що регламентують фінансові правовідносини. Конституційні засади права вимоги у фінансовому праві - це система правових положень, принципів фінансового права, на основі яких повинна будуватися вся фінансова правова дійсність, що знайшли своє відображення в Основному Законі - Конституції України, і в силу цього отримали статус загальнообов'язкових. Прикладом нормативного 
закріплення права вимоги у Конституції України є стаття 67 Конституції України - кожен зобов'язаний сплачувати податки і збори в порядку і розмірах, встановлених законом [9]. Саме дана стаття виступає «нормою принципом», яка відрізняється від інших норм широтою та важливістю сформульованих в ній положень. Вона визначає зміст інших норм фінансового законодавства, $\epsilon$ для них правовою основою. Оскільки дана норма встановлює основу права вимоги у податковому зобов'язанні, і саме вона надає право вимоги органам державної влади від імені держави вимагати у платників податків виконання обов'язку по його сплаті. Тому, можна вважати, що конституційні засади фінансового права, а зокрема норма що містяться в Конституції, виступають нормативною підставою як для виникнення права вимоги, так і для його здійснення. I чим вище рівень розвитку громадянського суспільства і правової держави в тій чи іншій країні, тим більше повно і чітко на рівні Конституції держави регламентуються підстави фінансового права, формуються конституційне фінансове право. На сьогодні в Конституції України нормативно зафіксовано тільки два принципи оподаткування - їхній загальний характер i необхідність їх законодавчого оформлення. Тобто в даному випадку можна говорити про певну випадковість конституційноправових положень податкового права. Але разом 3 тим дані положення не можуть залежати від випадковості, згідно з якою одні питання знайшли в тексті Конституції повне відображення, а інші - ні. Ті чи інші положення є принципами не тому, що вони містяться в Конституції - їх фіксування в ній лише надає їм відповідний нормативний статус, канонізує їх - а тому, що вони виражають гносеологічну сутність відповідного зрізу права як феномена суспільного життя. Будучи такими феноменами споконвічно, за своєю власною природою, вони і відбираються законодавчою владою (у всякому разі, повинні відбиратися) для наступного їх нормативного втілення [27, с. 98]. Цінність у нормативному, насамперед конституційному втіленні податкового права в цілому, полягає в тому, що податкове право стає могутнім інструментом узгодження публічних та приватних інтересів, є засобом, який відображає природну перешкоду на шляху зловживання податковим правом i, разом із тим, $\epsilon$ основою для справедливого та співрозмірного оподаткування.

Наступним способом в якості об'єктивізації права вимоги варто виділити фінансовий закон. Вимога законодавчого 
Права людини в Україні та у зарубіжних країнах: традиції та новації

оформлення фінансового права $\epsilon$ одним з постулатів сучасного фінансового права. Встановлення податку у формі закону дозволяє уникнути при оподатковуванні порушення одного 3 базисних, вихідних засад Конституції - принципу недоторканності приватної власності. По-друге, формулюючи загальнообов'язкові вимоги з питань оподатковування у формі закону, публічна влада випереджає спробу обговорення податків на предмет їхньої доцільності, оскільки режим законності передбачає безумовне виконання законів. За допомогою положень спеціального законодавства суб'єкти, які вступають у податкові відносини, можуть мати чітку визначеність стосовно прав, обов'язків та гарантій у відповідний період [6, с. 159]. Проблемою $\epsilon$ те, що важко на сьогодні розмежовувати поняття «податкове законодавство» та «акти законодавства про податки і збори». Нормативні акти представлені як законами (спеціальними, які регулюють конкретну галузь права, i загальними), так і нормативними актами компетентних органів (представницьких i виконавчих органів державної влади, місцевого самоврядування, органів управління спеціальної компетенції). Податкове законодавство якраз і включає систему цих нормативних актів. Так, відповідно до ст. 3 Податкового кодексу України, податкове законодавство України складається 3 Конституції України; Податкового кодексу України; Митного кодексу України та інших законів 3 питань митної справи у частині регулювання правовідносин, що виникають у зв'язку з оподаткуванням ввізним або вивізним митом операцій 3 переміщення товарів через митний кордон України (законами 3 питань митної справи); чинних міжнародних договорів, згода на обов'язковість яких надана Верховною Радою України і якими регулюються питання оподаткування; нормативно-правових актів, прийнятих на підставі та на виконання ПК України та законів 3 питань митної справи; рішень Верховної Ради Автономної Республіки Крим, органів місцевого самоврядування з питань місцевих податків та зборів [18].

Отже, право вимоги як елемент суб'єктивного фінансового права не може виникнути без об'єктивізації у нормах об'єктивного права. Саме вольовий зміст права в цілому і фінансового права зокрема, визначаючи його сутнісні ознаки, $\epsilon$ вихідним, базисним чинником i дозволяє нам розкрити вертикальний зріз системи фінансового права. До такої системи включаються начала фінансового права, принципи фінансового 
Права людини в Україні та у зарубіжних країнах: традиції та новації

права, конституційні засади фінансового права, юридичні конструкції фінансового права, фінансовий закон.

У сфері забезпечення виконання обов'язку по відношенню до права вимоги уповноваженої сторони правовому регулюванню належить надзвичайно важлива, конструктивна роль. Тому перш за все необхідно визначити основні моменти, що створюють основу для здійснення права вимоги, виходячи із інтересів як уповноваженого, так і зобов'язаного суб'єктів - необхідна їхня взаємна персоніфікація; слід надати сторонам можливість обміну інформацією, що перетворює їх в уповноваженого та зобов'язуваного; сторони повинні мати можливість реалізовувати права і виконувати обов'язки, включаючи контроль за виконанням на користь уповноваженого суб'єкта; у випадку виникнення необхідності захисту порушеного права сторони повинні бути зацікавлені у продовженні своїх відносин, але вже у судовій або адміністративній процедурі; сторони і після завершення фінансових операцій зберігають взаємопов'язаність та зацікавленість у ній як джерелі доказів про походження відповідних коштів, підставах їх сплати та можливості їх повернення або іншого використання в інтересах платника; створення умов, за яких переважна частина фінансових операцій пов'язана 3 реалізацією інших подібних операцій або здійсненням цивільно-правових угод за участю цих же сторін.

\section{Висновки}

Для права вимоги у фінансовому праві характерні такі особливості: право вимоги виявляється безглуздим, якщо воно не пов'язане $з$ можливістю користування якимись соціальними благами; право вимоги $\epsilon$ лише різновидом власних дій уповноваженої особи; при негативному праві вимоги використання права на власні дії в юридичному аспекті не потребує сприяння зобов'язаних осіб, їх число невизначено, не персоніфіковане (наприклад, фактичне використання речі) - у такому випадку правовідносин немає; право вимоги активних дій припускає конкретний склад юридично зобов'язаних суб'єктів, і без їхніх дій уповноважений не може здійснити своє право - у даному випадку правовідносини є необхідними; у фінансових правовідносинах право вимоги реалізується у двох формах активній - вимога до зобов'язаного суб'єкта виконати активні обов'язки - тут право вимоги передбачає здійснення зобов'язаним суб'єктом комплексу активних дій, пов'язаних із 
Права людини в Україні та у зарубіжних країнах: традиції та новації

виконанням суб’єктивного фінансового (бюджетного, податкового) обов'язку; пасивній формі - тут право вимоги передбачає покладання на зобов'язаного суб'єкта пасивних обов'язків (утримання від здійснення дій, які заборонені або здійснювати які суб'єкт не має права); у переважній більшості випадків правом вимоги наділені уповноважені державні органи, які представляють державу в бюджетних правовідносинах, та уповноважені органи місцевого самоврядування, які представляють адміністративно-територіальні утворення.

При здійсненні права вимоги вирішальне значення мають принципи суб'єктивного права, адже право вимоги визначається як його основний елемент поряд із правом на власні дії та правом на захист: принцип забезпеченості права вимоги у фінансовому; принцип демократизму права вимоги; принцип активності права вимоги; принцип фінансового заохочення суспільно корисної поведінки; принцип безпосередності; принцип реальності права вимоги; принцип гуманізму; принцип свободи; принцип законності; принцип справедливості; принцип регулятивності права вимоги.

Важливим у частині реалізації права вимоги є визначення системи критеріїв правового регулювання, котрі забезпечують можливість його здійснення: критерій недостатності чинного правового регулювання; критерій придатності вже існуючого правового регулювання реалізації права вимоги; критерій можливості застосування наявного правового регулювання суб'єктами права вимоги для яких воно призначене.

Право вимоги у податковому зобов'язанні визначається принципом однобічного запровадження податків та примусового ïx стягнення. Аналіз норм податкового законодавства дає можливість виділити податкові права вимоги уповноважених державних органів, а в процесі здійснення конституційного обов'язку зі сплати податків платники податків можуть виступати із зустрічними вимогами по відношенню до органів державної влади.

Аналіз бюджетного законодавства демонструє, що спірним моментом у визначенні права вимоги у бюджетному зобов'язанні $\epsilon$ те, що законодавець не враховує випадки виконання таких зобов'язань між самими ж розпорядниками бюджетних коштів, а також не враховує права вимоги місцевих бюджетів на дотації та субвенції (міжбюджетні трансферти), 
Права людини в Україні та у зарубіжних країнах: традиції та новації

котрі встановлюються Законом України «Про державний бюджет України» на поточний рік.

\section{Список використаних джерел:}

1. Фінансове право: навч. посібник (За законодавством України) / За ред. Воронової Л.К. і Бекерської Д.А. Київ : Вентурі, 1995. 272 c.

2. Хохуляк В.В. Публічний інтерес як категорія науки фінансового права. Наук. вісн. Чернівец. ун-ту. 2004. Вип. 236. Правознавство. С. 5-10.

3. Іванчук Н.В. Взаємна відповідальність особи і держави в контексті розбудови сучасної української держави : дис... канд. юрид. наук : 12.00.01. Київський національний ун-т внутрішніх справ. Київ, 2007. С. 185.

4. Лисенков С. Способи правової регламентації і реалізація суб’єктивних прав. Юридичний журнал : Аналітичні матеріали, коментарі, судова практика. 2006. № 4. С. 93-95.

5. Пацурківський П.С. Критерій правового начала - принцип формальної рівності суб'єктів правовідносин - і пострадянське фінансове право: проблеми теорії. Право України. 2008. № 1 . С. 10-15.

6. Вдовічен В.А. Податково-правовий компроміс інтересів платника податків і держави: монографія. Чернівці : Чернівецький нац. Ун-т, 2012. 272 с.

7. Черних Є.М. Об'єктивне і суб'єктивне право: теоретикоправові аспекти співвідношення : автореф. дис... канд. юрид. наук ; Київ. нац. ун-т внутр. справ. Київ, 2008. 20 с.

8. Шлоер Б. Принцип адекватності в європейському та українському публічному праві. Украӥнський правовий часопис. 2003. № 3(8). С. 3-27.

9. Конституція України: прийнята на п'ятій сесії Верховної Ради України Законом України від 28.06.1996 № 254к/96-ВР. Відомості Верховної Ради України. 1996 р. № 30. Ст. 141.

10. Гаврилюк Р.О. Юридична конструкція податку. Право Украӥни. 2006. № 4. С. 113-117.

11. Науково-практичний коментар Бюджетного кодексу України / Кол. авт.: В.І. Антипов, Л.К. Воронова, Н.В. Воротіна та ін.; за заг. ред. проф. П.В. Мельника; ДПА України, НАДПС України, АПрНУ, НДІФП. Київ : Юрінком Інтер, 2003. С. 321-329.

12. Про зміцнення фінансової дисципліни та запобігання правопорушенням у бюджетній сфері: Указ Президента України 
Права людини в Україні та у зарубіжних країнах: традиції та новації

№ 1251/2001 від 25.12.2001 р. Офіційний вісник України від 11.01.2002 - 2001 р., № 52. Стаття 2335.

13. Бюджетний кодекс України від 08.07.2010 № 2456-VI. Відомості Верховної Ради України. 2010. № 50. С. 1778. Ст. 572.

14. Кодекс України про адміністративні правопорушення. Відомості Верховної Ради УРСР від 18.12.1984. № 51, стаття 1122.

15. Кримінальний кодекс України. Відомості Верховної Ради України. 2001. № 25-26. Ст. 131.

16. Бабін I.I. Податкове право України : навч. посібник. Чернівці : Чернівецький нац..ун-т, 2012. С. 195-196.

17. Кучерявенко Н.П. Система налоговых органов Украины. Харьков, 2000. С. 102-111.

18. Податковий кодекс України від 02.12.2010 № 2755-VI. Відомості Верховної Ради України від 08.04.2011. № 13, / № 13-14, № 15-16, № 17. С. 556. Ст. 112.

19. Кучерявенко Н.П. Курс налогового права. В 6 томах. / Н.П. Кучерявенко. Т. III: Учение о налоге. Харків : Легас; Право, 2005.

20. Щербанюк О.В. Громадянин як суб'єкт податкових правовідносин. Чернівці : Рута, 2000. 278 с.

21. Стефанчук М. Зловживання правом як новела цивільного законодавства. Юридична Україна. 2004. № 6. С. 38-42.

22. Задорогин 0. Правовое регулирование оптимизации налогообложения в Российской Федерации: вопросы теории и практики : дисс. ... канд. юрид. наук. Москва, 2004. 190 с.

23. Савсерис С.В. Категория «недобросовестность» в налоговом праве. Москва : Статут, 2007. 191 с.

24. Чернадчук В.Д. Бюджетні правовідносини в Україні: поняття, класифікація та особливості структури : монографія. Суми : Університетська книга, 2011. 172 с.

25. Кучерявенко М.П. Курс налогового права. В шести томах. T. 1. Генезис налогового регулирования (В 2-х частях). Ч. 1. Харьков : Легас, 2002. 666 с.

26. Гаджиев Г.А., Пепеляев С.Г. Предпринимательналогоплательщик-государство. Правовые позиции Конституционного суда Российской Федерации: Учебное пособие. Москва : ФБК-ПРЕСС, 1998. С. 194-197.

27. Гаврилюк Р.О. Діалектика змісту та форми податкового права як відображення його системної сутності. Науковий вісник Чернівецького університету. 2005. Випуск 282. Правознавство. C. 96-102. 